\title{
Coleção A.B.O. 1986 - 2005
}

\author{
Harley E. A. Bicas
}

Junto a este número dos Arquivos Brasileiros de Oftalmologia você está recebendo a mais nova edição do CD contendo os artigos publicados nos ABOs de 1986 a 2005.

Levar no bolso vinte anos de publicações dos Arquivos Brasileiros de Oftalmologia não apenas representa enorme comodidade para consultas de trabalhos publicados, mas também uma garantia de suas reproduções e preservações, assim como de facilitações de suas divulgações e de intercâmbios de informações. É inegável, sobretudo, a economia relativamente à apresentação impressa, tanto em termos materiais quanto a de espaços, pela compactação desse acervo de vinte anos, que estaria contido em mais de um metro de prateleira de uma estante comum.

Todas essas vantagens oferecidas pela moderna tecnologia podem mudar. De fato já vão mudando, embora suas matrizes se conservem e a substituição da atual pelas seguintes seja mais simples que a da comunicação tradicional e até há pouco prevalente para as gravações digitais.

Por tudo isso é que muito nos orgulha esse salto de qualidade na apresentação dos Arquivos Brasileiros de Oftalmologia e a manutenção de sua memória. Aliás, a primeira edição desta coleção em formato compactado foi a de quando se fez a do período de dez anos, desde 1986. Esta é a sétima, reproduzindo as anteriores e agregando, agora, o que se publicou de 2001 a 2005 (inclusive).
Fonte de pesquisas sobre a literatura oftalmológica nacional mais recente e importante material de educação continuada, o que se tem neste disco é a condensação de esforços apurados de autores, analistas e editores, mostrando a contínua ascensão sobre o que aqui se faz de ciência e prática nesta nossa apaixonante arte.

O presente CD contém 1.789 trabalhos na íntegra e mais 5.457 resumos de Temas Livres e Painéis, apresentados nos Congressos Brasileiros de Oftalmologia e nos de Prevenção da Cegueira e Rehabilitação Visual. Todo esse material pode ser pesquisado de maneira rápida e eficiente, com mecanismos de busca de artigos científicos por descritores ou palavras-chave, por instituição participante no trabalho científico, pelo titulo ou pelo nome dos autores. Também há um índice que se inicia no volume 49 (1986) e vai até o volume 68 (2005), mostrando edição por edição dos ABO. Uma ferramenta realmente amigável ao usuário.

Os artigos completos poderão ser consultados e impressos sob o formato PDF (Portable Device Format). Para tanto, basta ter o programa Adobe Reader, que pode ser obtido gratuitamente no site www.adobe.com.

Dessa forma, esperamos que este serviço de muita utilidade, seja mais um dos que presta o CBO a seus associados, agregando-lhes valor às suas contribuições de filiação. 